\section{Væske- og elektrolyttbehandling - en god veileder}

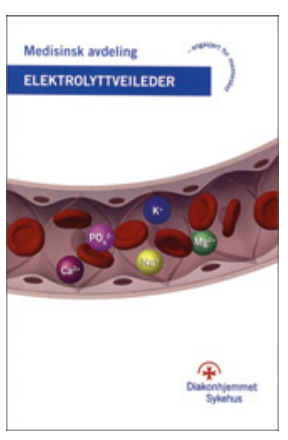

Kiarash Tazmini, Tonje T. Johansen Elektrolyttveileder

19 s, ill. Oslo: Diakonhjemmet sykehus, 2012 Pris Gratis

Væske- og elektrolyttbehandling er trolig den mest hyppige, parenterale terapien ved våre sykehus. Knapt noen somatisk pasient slipper i dag unna. Tross hyppig bruk er det mye tilfeldig og kanskje skadelig behandling som gis. Årsaken til dette er dels at feltet ofres liten interesse og at mange tror de behersker området godt. En måte å bøte på dette er å ha kunnskap om emnet lett tilgjengelig, for eksempel i form av heftet Elektrolyttveileder.

Dette lille heftet utgis i lommeformat og fungerer som en påminnelse og veileder i korrekt bruk av både elektrolytter og væske ved «sengekanten». Heftet har et oversiktlig oppsett med god bruk av tabeller og farger. Det er også satt av plass til egne notater. Dette er ingen lærebok, men en huskeliste for dem av oss som ikke til enhver tid har innholdet $i$ Ringer-acetat i hodet.

Heftet har tabeller over hva som kan tilsettes av elektrolytter, og hvor mye, i ulike infusjonsløsninger. Forfatterne viser også innholdet i slike løsninger og vanlig døgnbehov. Til slutt er det enkle omtaler og noen formler til bruk i utregningen av over- og underskudd på vanlige væske- og elektrolyttforstyrrelser som hyper- og hyponatremi.

En kort innledning bør være med i neste utgave. Der bør det stå hvilke pasientgrupper som er målgruppen - etter min mening er det pasientene på vanlige sengeavdelinger. På intensivavdelinger har man ofte andre retningslinjer for hva som kan godtas, for eksempel bruker man der ofte ufortynnet kaliumklorid som kontinuerlig infusjon via sentralvenekateter.

Noen mindre detaljer som også bør rettes opp senere, er mangelen på omtale av den viktigste elektrolyttforstyrrelsen, nemlig hypokalemi. Jeg synes også det bør stå noen ord om faren for for rask stigning av serum-natrium ved alvorlig hyponatermi $(<120 \mathrm{mmol} / \mathrm{l}) \mathrm{og}$ anbefalt hastighet (ikke øk serum-natrium $>0,5 \mathrm{mmol} /$ time). Under omtale av kalsiumklorid står en indikasjon som ikke har med hypereller hypokalsemi å gjøre, nemlig hypokalemi. Jeg synes dette kan tas ut da det er mer en farmakologisk bruk av kalsiumklorid. Det burde i så fall vært tatt med under et eget avsnitt om hyperkalemi, som også mangler. På side 12 står en oppskrift på «hjemmelaget» hyperton natriumklorid. Det er bra, for av en eller annen grunn er det ikke mulig å få tak i ferdig produsert hyperton natriumklorid i Norge lenger.

Jeg anbefaler heftet varmt som en enkel måte å forbedre væskeog elektrolyttbehandlingen ved våre sykehus og sykehjem.

\section{Hans Flaatten}

Kirurgisk serviceklinikk

Haukeland universitetssykehus

\section{Populærvitenskapelig fremstilling i nevrovitenskap}

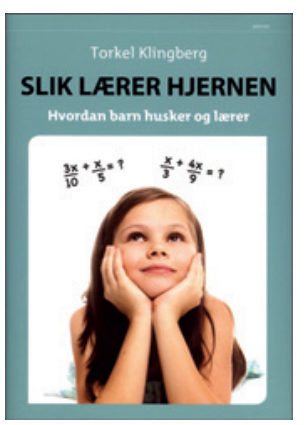

\author{
Torkel Klingberg
}

\section{Slik lærer hjernen}

Hvordan barn husker og lærer. 178 s, ill.

Oslo: Pax Forlag, 2012. Pris NOK 299

ISBN 978-82-530-3441-6

Nevrovitenskap omfatter forskningsbasert kunnskap om nervesystemet. Begrepet er sammensatt og tar for seg mange forskjellige fagområder. Feltet har vært i en rivende utvikling de siste årene, og mange spår at kunnskap om hjernen, dens utvikling, funksjon og sykdommer vil øke formidabelt $\mathrm{i}$ årene som kommer.

Torkel Klingberg, som er professor i kognitiv nevrovitenskap ved Karolinska institutet, har i Slik loerer hjernen satt seg som mål å fremstille noen av de nevrovitenskapelige nyhetene på en populærvitenskapelig måte. Langt på vei lykkes han. Han konsentrerer seg i hovedsak om barn og tar for seg hvordan man i dag forstår læreprosessene ut fra et nevrobiologisk perspektiv. Boken er krydret med tallrike kliniske eksempler som gjør stoffet lett tilgjengelig. Noe av Klingbergs mål er å knytte en god faglig forbindelse mellom pedagogikk og den kognitive nevrovitenskapen. Han lykkes et stykke på vei med dette.

Som en basis tar forfatteren for seg hjernens vekst og utvikling. Dette kapitlet er kanskje ikke helt oppdatert, men det gjør egentlig ikke så mye. Det danner et godt grunnlag for det som han behandler i de andre kapitlene. I kapittel 1 tar forfatteren for seg betydningen av arbeidsminnet, og han forklarer minnets relasjon til konsentrasjon og oppmerksomhet. Videre beskriver han utvikling og kjønnsforskjeller og utviklingsforstyrrelser hvor arbeidsminnet er affisert. Han tar også for seg begrepet langtidshukommelse og gir en fremstilling av noen av de forskningsaspektene som er aktuelle. Forfatteren klarer å gi en lettfattelig fremstilling av et særdeles komplisert emne, uten at dette går ut over fagligheten. Han tar også for seg andre emner, bl.a. hvordan hjernen forholder seg til stress, miljøpåvirkninger og betydningen av kognitiv trening og musikkterapi. Et godt pluss er at kapitlene forholder seg ryddig til hverandre. Språket er klart, og layouten er tilfredsstillende.

En slik bok som dette krever gode og instruktive illustrasjoner. Her holder den dessverre ikke mål. Det hadde vært en stor fordel for forståelsen om illustrasjonene hadde vært i farger. I tillegg burde man ha benyttet seg av langt flere illustrasjoner enn hva som er tilfellet, og en del av dem skjemmes av unøyaktigheter og feil.

Innenfor helsevesenet passer kanskje boken best for sykepleiere som jobber med barn og ungdom. I utgangspunktet er det begrenset hvor god nytte leger vil ha av den. Dersom man vil ha en rask, lettlest og morsom innledning til det nevrovitenskapelige fagfeltet, kan den imidlertid være en fin investering. Boken passer ellers for pedagoger som ønsker å sette seg litt mer inn i nevrobiologiske aspekter.

Ola H. Skjeldal

Vestre Viken 